\title{
СВІТЛОЇ ПАМ'ЯТІ ПРОФЕСОРА ТАМАРИ ТРОХИМІВНИ ЧОРНОЇ
}

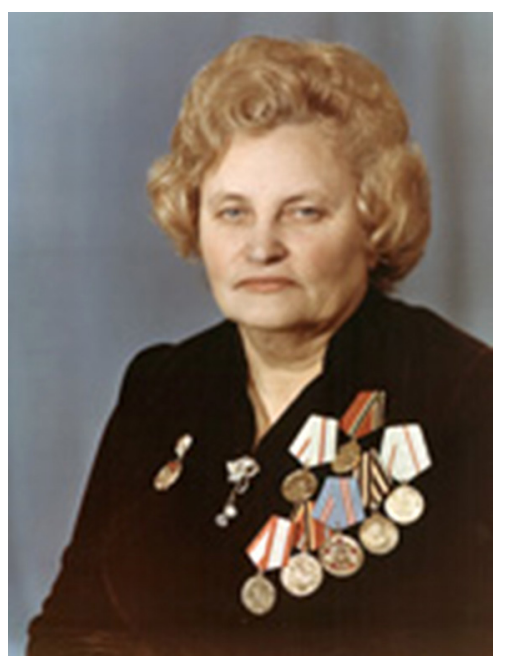

28 травня 2016 р. на 97-му році пішла з життя Тамара Трохимівна Чорна, інфекціоніст-клініцист, ветеран Другої світової війни, доктор медичних наук, професор.

Тамара Трохимівна народилася 1 травня 1920 р. в селі Жолоби Томашпільського району на Вінниччині у селянській сім'ї. До тодішніх суспільних потрясінь - громадянської війни, руйнації, голоду додалася передчасна смерть батька внаслідок перенесеного висипного тисру, що стало тяжким випробуванням для багатодітної родини, п'ятою і найменшою дитиною в якій була півторарічна Тамара.

Ще з дитинства Тамара захоплювалася медициною, якій у майбутньому і було присвячено близько 75 років життєвого шляху. Дитяча мрія стати лікарем почала реалізовуватися в 1938 р., коли вона вступила до Київського медичного інституту, навчання в якому поєднувала з роботою вакцинатором в районній санітарно-епідеміологічній станції м. Києва. Подальшу життєву долю, як і більшості її ровесників, зумовила трагічна сторінка в історії людства - Друга світова і Радянсько-німецька війна 1941-1945 рр., з перших днів якої Тамара Трохимівна на собі відчула їі смертоносний тягар і подих. Тільки-но склавши екзамени по завершенні третього курсу, разом з іншими студентами Київського медичного інституту вона була направлена на спорудження укріплень протитанкової оборони на захід від Києва, а потім - евакуація інституту, 600 км пішки від Києва до Харкова під обстрілами та бомбардуваннями нальотів ворожої авіації, перші людські втрати - поранені, скалічені, убиті... По прибутті до Харкова - прискорене навчання вдень, чергування в госпіталях біля тяжкопоранених вночі. В 1942 р. Тамара Трохимівна Чорна закінчує лікувальний фракультет Київського медичного інституту, який вже на той час був евакуйований до Челябінська. Маючи вибір - робота лікарем у тилу або на передовій, вона без вагань добровільно обирає передову фронту. Після проходження двомісячних курсів удосконалення медичного складу Радянської Армії в Москві Т.Т. Чорну спочатку в якості лікаря роти, а потім капітана медичної служби було направлено в епіцентр кривавих подій Другої світової, у Сталінград. Через багато десятиріч по тому, нелюдські умови та страждання, постійне відчуття дихання та присутності смерті, гіркоту небачених до того людських втрат на передовій під час оборони Сталінграду Тамара Трохимівна відобразила у своєму ліричному й одночасно трагічному вірші: «Сестра, сестричка, медсестра...». Вона пройшла через жерло найкривавішої в історії людства війни, беручи участь у бойових діях на Сталінградському, Ленінградському, 1-ому та 2-ому Прибалтійському та Донському фрронтах. За мужність і героїзм, проявлені при наданні медичної допомоги пораненим бійцям, начальника медичної служби батальйону Тамару Трохимівну Чорну було нагороджено багатьма медалями і орденом Вітчизняної війни 1-го ступеня.

3 настанням мирного життя Т.Т. Чорна працює спочатку епідеміологом, а потім головним лікарем Томашпільської районної санепідемстанції. Але потяг до нових знань, наукової роботи не полишав Тамару Трохимівну, а тому в 1951 р. вона вступає до клінічної ординатури Київського медичного інституту, після закінчення якої призначається асистентом кафедри інфекційних хвороб цього ж інституту. В 1956 р. Т.Т. Чорна захистила кандидатську дисертацію, присвячену імунодіагностиці черевного тифу в умовах антибіотикотерапії. На той час її вчителі - це відомі науковці Л.В. Громашевський, А.М. Зюков, Б.Я. Падалка, О.Ф. Білібін та ін.

В 1968 р. Т.Т. Чорна переїжджає із Києва до Харкова, де починає працювати у Харківському медичному інституті (XMI), з яким пов'язує весь свій подальший трудовий шлях. Тут вона стає доцентом кафедри інфекційних хвороб, а в 1969 р. за конкурсом обирається на посаду завідуючої касредри. В 1973 р. захищає дисертацію доктора медичних наук, у якій висвітлила особливості перебігу інсрекційних хвороб у осіб похилого віку. В 1976 р. їй було присуджено звання професора. 
Роки плідної роботи Т.Т. Чорної на кафедрі й у клініці інсрекційних хвороб XMI назавжди й заслужено закріпили за нею по-справжньому авторитет ерудованого викладача, далекоглядного вченого, високопрофесійного інфекціоніста-клініциста, високоосвіченої та порядної людини.

На території клініки інфекційних хвороб, у самій будівлі клініки й до тепер залишилося багато з того, що було задумано та зроблено професором Т.Т. Чорною - це посаджений нею разом зі студентами-медиками наприкінці 60-х років минулого сторіччя березовий гай поряд з клінікою дитячих інфекційних хвороб, вперше створена нею база застосування лазерного опромінювання у пацієнтів на різноманітні інсеекційні захворювання та їх ускладнення, розроблені під її керівництвом підходи, методики викладання курсу інорекційних і паразитарних хвороб, тропічної медицини, створена ії зусиллями школа лікарів-інсекціоністів, педагогів і вчених.

Завдяки її зусиллям, старанню та далекоглядності в навчальну, лікувальну, науково-дослідницьку роботу касредри впроваджуються нові та прогресивні на той час підходи, інноваційні технології, багато з яких було застосовано вперше. Впроваджується та застосовується новий напрямок лікування інфекційних хвороб - лазеротерапія.

За роки завідування кафедрою та з ініціативи Т.Т. Чорної була придбана нова апаратура та устаткування: техніка для світлової та люмінесцентної мікроскопії, інгалятори, апарати для лазерної терапії та дослідження функції респіраторної системи, відповідно обладнані кабінети імунофрлюоресцентної діагностики, аерозольної терапії із застосуванням тепловологих електроаерозолів, кабінети лазерної та фрізіотерапії, діагностики функції зовнішнього дихання і стану мікроциркуляторного русла за допомогою мікроскопії бульбарної кон'юнктиви. Все це значно розширило можливості наукових досліджень, сприяло наглядності та підвищенню якості навчального та лікувального процесів.

Особливу роль Т.Т. Чорна надавала студентському науковому товариству кафедри, роботою якого особисто опікувалася аж до самого виходу на пенсію.

Із 1970 р. за ініціативи Т.Т. Чорної на кафедрі було запроваджено проведення наукових студентських конференцій з тропічних інфекцій серед іноземних студентів. Надалі такі конференції стають традиційними й проводяться дотепер. Для удосконалення навчального процесу запроваджено метод проблемного читання теоретичного курсу інфектології. Лекції та практичні заняття забезпечуються сучасними технічними засобами ілюстрації та наглядності матеріалу. Лекції Т.Т. Чорної вирізнялися відточеною педагогічною майстерністю, чіткою добіркою інфрормації та матеріалу, клінічними ілюстраціями та прикладами, емоційно-яскравою мовою.

До вагомих наукових доробок Т.Т. Чорної належить впровадження фуункціональних, морфологічних, імуно- фрлюоресцентних, імунологічних та гістохімічних методів дослідження, застосування етіопатогенетичного напрямку в лікуванні хворих на дизентерію, бешиху, вірусні гепатити, грип тощо.

Досягнення школи вчених-іноекціоністів, котру очолювала Тамара Трохимівна Чорна, викладені в більш ніж 200 наукових публікаціях та десятках патентів на винаходи. За час її роботи на кафедрі підготовлено 9 кандидатів медичних наук, тисячі вітчизняних та іноземних спеціалістів. Серед ії багатьох вдячних учнів чимало відомих, авторитетних, успішних та знаних людей України, близького та далекого зарубіжжя. Всі, з ким розділяєш спогади про цю непересічну людину, одностайно зазначають, що Тамара Трохимівна поєднувала у собі душевну простоту й доступність для спілкування, ії мові були притаманні особливий яскравий колорит і виразність, зрозумілість і чіткість думок, оригінальність і довершеність.

Назавжди в пам'яті тих, кому пощастило працювати поруч з Тамарою Трохимівною, залишилися її змістовні та пізнавальні професорські обходи хворих, неповторні, оригінальні та лаконічні вислови, які стали крилатими: «Богиня - клініка», «Є гарячка - шукай екзантему», «Не буває грипу без трахеобронхіту».

Здоров'я і життя хворих для Тамари Трохимівни Чорної завжди були найвищими й беззаперечними цінностями. В будь-який час дня і ночі вона завжди відкликалася на прохання оглянути хворого, допомогти колегам і молодим лікарям розібратися у складній діагностичній ситуації. Через багато років співробітники клініки та врятовані профресором Т.Т. Чорною пацієнти з особливим почуттям вдячності згадують непоодинокі випадки, коли вона по декілька днів залишалася в клініці в найтяжчий для хворих період захворювання.

Протягом всього життєвого шляху ідеалами профресора Тамари Трохимівни Чорної були чесність, порядність і справедливість, працьовитість і самовіддача, любов і співчуття. Саме тому до неї приходили за порадою, зверталися за допомогою: частіше зі своїми проблемами та хворобами, так як були впевнені, що у Тамари Трохимівни завжди знайдеться спеціально для них припасений рятівний рецепт, у вигляді гірких ліків чи у вигляді душу зігріваючих слів.

3 виходом у 2000 р. на заслужений відпочинок Тамара Трохимівна не поривала зв'язків з університетом, колегами, кафедрою й активно провадила наукову, освітянську та лікувальну роботу. Практично до останніх днів свого життя вона безкорисливо надавала пацієнтам консультативну допомогу, проводила патріотично-виховну роботу серед молоді та студентства університету, іiї публікації та творчі доробки друкувалися у місцевих періодичних виданнях та в газеті «Медичний університет». 


\section{ЮВІЛЕї ТА ПОДії}

Простота в спілкуванні, відданість своєму професійному обов'язку, висока освіченість, чесність, красива мова - назавжди полонили душу кожного, кому пощастило знати Тамару Трохимівну. Вона добре знала та любила поезію Лесі Українки, класичну вітчизняну та зарубіжну літературу, мала свій скромний поетичний доробок. Т.Т. Чорна виховала доньку, яка теж стала лікарем, а онук обрав її шлях професію інфекціоніста, працює викладачем та займається науковою роботою.

Тепер, коли нашого Вчителя немає поруч з нами, як ніколи гостро ми відчули глибину та непоправність втрати. Учні Тамари Трохимівни глибоко вдячні їй за безцінні уроки професійної майстерності, морального обов'язку, високої відповідальності при виконанні лікувальної, педагогічної та наукової роботи.
Зірка на небі згасла...

Миттєво відчули ми темряву ночі.

Пішла від нас у вічність

Професор Тамара Трохимівна Чорна.

Вчитель, вчений, лікар від Бога,

Одне слово - Людина з великої літери...

Вона любила всіх нас так,

Немов би всі ми - ії діти.

Зірки на небі не стало...

Але світлу від неї іще довго світити.

Ми вдячні долі, вдячні Богу,

що нас зростив Великий Вчитель!

Колектив кафредри інфрекційних хвороб Харківського національного медичного університету, обласної клінічної інфрекційної лікарні м. Харкова.

Отримано 22.09.2016 р. 